Egyptian J. of Nutrition Vol. XXXIII No. 2 (2018)

\title{
Therapeutic Effect of Banana Flower (Banana Male Bud) on Diabetic Rats
}

\section{Ibrahim S. Salem, Ahmed A. Ameen and Mona S. Mohammed}

\author{
Nutrition and Food Science Dep., Faculty of Home Economics, \\ Helwan University, Cairo, Egypt
}

\begin{abstract}
The present study aimed to evaluate the effect of four concentrations of dried banana male bud (DBMB) on blood glucose level in male diabetic rats. Thirty male albino rats were divided into two main groups; first group: as control negative $(n=5)$ and second group: diabetic rats $(n=25)$, divided into five equal subgroups as follows: diabetic untreated rats (as control positive), diabetic rats treated with $2.5 \%, 5 \%, 7.5 \%$ and $10 \%$ DBMB. Results of the biological study revealed that injection rats with alloxan exhibited hyperglycemia and elevation in lipid profile (cholesterol, triacylglycerol \& VLDL-c), liver enzymes aspartate and alanine aminotransferase (AST \& ALT), and kidney function (uric acid \& urea nitrogen). Treatment with the four levels of DBMB revealed gradual improvement in serum glucose, triacylglycerol, VLDL-c and all the other parameters when compared to untreated diabetic group. The most pronounced improvement was in the treated group that received the highest level of DBMB. The histopathological examination of liver, kidney and pancreas tissues confirmed this improvement at treatment with $10 \%$ DBMB. Fortified pan bread with 5\% DBMB showed the best results in most of the sensory properties. In conclusion, the present
\end{abstract}




\section{Ibrahim S. Salem, Ahmed A. Ameen and Mona S. Mohammed}

study illustrates that DBMB has potent hypoglycemic activity and can be used as a supplement in the diet of diabetics.

\section{Introduction}

Diabetes mellitus, which has become one of the most drastic metabolic disturbances in the world, is diagnosed by absolute or relevant deficiencies in insulin secretion and/or insulin action, followed by chronic hyperglycemia (Nia et al., 2018). It has caused a significant morbidity and mortality due to microvascular (retinopathy, neuropathy and nephropathy) and macrovascular (heart attack, stroke and peripheral vascular disease) complications (Patel et al., 2011).

Therapeutic options for diabetes are diet, exercise, oral hypoglycemic drugs, and insulin therapy. Treatment with oral hypoglycemic agents is associated with side effects related to pharmacokinetic properties, secondary failure rates, hypoglycemia, gastrointestinal disturbances, skin reactions, hematological disorders, and rise in hepatic enzyme level (Kumar et al., 2015).

Diet therapy along with insulin and drugs is more effective in combating diabetes and its complications. Prior to introduction of therapeutic use of insulin, diet therapy was the main form of treatment, and dietary measures included the use of traditional medicines mainly derived from plants. Diet therapy works through different mechanisms like inhibiting glucose production, decreasing absorption of glucose in gastro-intestinal tract, increasing production of insulin by $\beta$-cells in the pancreas, or by mimicking insulin activity (Bhaskar et al., 2011b). 


\section{Egyptian J. of Nutrition Vol. XXXIII No. 2 (2018)}

Banana plant, often erroneously referred to as a "tree", is the largest herbaceous flowering plant (Rajesh, 2017). Banana belongs to the family Musaceae, genus Musa and is a general term embracing a number of species or hybrids in this genus (FAO, 2002). Banana (Musa sp.) is considered one of the most important favorable and popular fruits in Egypt and all over the world (Mahmoud et al., 2014). Different parts of banana plant are known to be used in Ayurveda and other traditional folklore medicine for treatment of various diseases including diabetes (Bhaskar et al., 2011b). The use of other parts of the banana plant, such as leaves and sheaths, pseudostem, pith, and male bud, has been reported recently (Siddiq et al., 2012).

Bananas flowers are large, dark purple-red blossoms that grow from the end of a bunch of bananas. They are also called banana inflorescence, banana blossom, banana male bud (Florent et al., 2015)or banana heart (Swe, 2012;Salgar and Usman, 2015\&Singh, 2017). They are an agricultural by-product that is often consumed as vegetable in many Asian countries such Malaysia, Indonesia, Sri Lanka, Philippines and other South-East Asian countries. In Sri Lanka, it is consumed as a curry as well as a boiled or deep fried salad with rice and Wheat bread (Wickramarachchi and Ranamukhaarachchi, 2005). Besides being consumed fresh banana blossom can also be made into various products such as dehydrated vegetable, pickle and canned food (Sheng et al., 2010).

Also, dehydrated inflorescences (male flowers and bracts) are a great nutritive complement based on their high content of potassium and fiber. In view of their high nutritional value, inflorescences (male flowers and bracts) can be used in the diet in 


\section{Ibrahim S. Salem, Ahmed A. Ameen and Mona S. Mohammed}

the form of dehydrated flour and thus easily incorporated into food showed by Fingolo et al., (2012).

According to Sheng et al., (2010), banana flowers have tremendous nutritional value and healthy effects. They are used in treatment of bronchitis, constipation, ulcers and good for diabetics. It is traditionally believed to be beneficial as a lactating agent and helps to relieve painful menstruation. The banana flower is rich in phytochemicals like vitamins, proteins and flavonoids.

These banana blossoms are usually thrown away by producers in plantations and are one of the agricultural by-products which are getting more attention from many researchers and food manufacturers as a food source (Florent et al., 2015).

Therefore, the main target of the present study was to evaluate the therapeutic effect of different concentrations of dried banana flower (banana male bud) on male diabetic rats.

\section{Materials and Methods}

\section{Material}

\section{Plant material:}

Fresh banana male buds were obtained from Agriculture Research center, Giza, Egypt.

\section{Chemicals and Kits:}

Kits used for the quantitative determination of the different parameters were purchased from Biodiagnostic Co., Dokki, Giza, Egypt. Diethyl ether and formalin were obtained from Sigma-Aldrich Co. (St. Louis, MO, USA). Alloxan, Casein, vitamins and minerals constituents, sucrose and glucose were obtained from El- 


\section{Egyptian J. of Nutrition Vol. XXXIII No. 2 (2018)}

GomhoriyaCo., Cairo, Egypt. Cellulose was purchased from Morgan Co., Cairo, Egypt. Bread-making ingredients (wheat flour, instant yeast, white sugar, salt, and oil), corn starch and corn oil were obtained from a local market, Cairo, Egypt.

\section{Experimental Animals:}

Thirty male Sprague-Dawley rats weighing about (180 $\pm 10 \mathrm{~g})$ were purchased from the animal house of Helwan Station for Experimental Animals, Ministry of Health,Cairo, Egypt.

\section{Methods}

\section{Preparation of banana male buds Powder:}

Freshly banana (Musa acuminate L.) cultivar "Williams" male buds were washed with running tap water, cleaned, cut into slices and soaked in Citric acid solution, then dried at $40^{\circ} \mathrm{C}$ by hybrid solar convective drying system, belonging to the solar energy dept., National Research Center, Dokki Egypt, powdered, and stored at $4^{\circ} \mathrm{Cfor}$ further analyses.

\section{Chemical Analysis of dried banana male bud Chemical composition:}

Moisture, ash, protein, fat, and crude fiber were determined in dried banana male bud according to method described in (A.O.A.C. 2005).While; carbohydrate was determined by dinitrosalicylic acid method according to BeMiller, (2010).

Sugar composition:Sugars (glucose, fructose and sucrose) were determined by high performance liquid chromatography (HPLC) on an Agilent model 1100 series system (Agilent, USA). 
Ibrahim S. Salem, Ahmed A. Ameen and Mona S. Mohammed

Biological study

Preparation of Diets:

The standard diet was formulated according to AIN-93 (Reeves et al., 1993).

\section{Experimental Animal Design:}

Thirty male albino rats (Sprague-Dawley strain) weighing $(180 \pm 10 \mathrm{~g})$ were housed in well aerated cages under hygienic conditions, in Graduate Research Labs, Nutrition and Food Science Dept., Faculty of Home Economics, Helwan University, with free access to water and standard diet for one week for adaptation. After this period, rats were divided into two main groups, as follows:

\section{Thefirst group:}

Five rats fed on basal diet, served as control negative group.

\section{The second group:}

Twenty five rats were injected i.p. with alloxan (140 mg/kg b.wt.) (Pandurangan et al., 2013)to induce diabetes after fasting overnight and divided into five equalsubgroups as follows:

Subgroup (1): Diabetic untreated rats, fed on basal diet (as control positive group).

Subgroup (2): Diabetic rats treated withbasal diet containing $2.5 \%$ DBMB.

Subgroup (3): Diabetic rats treated with basal diet containing $5 \%$ DBMB.

Subgroup (4): Diabetic rats treated with basal diet containing $7.5 \%$ DBMB.

Subgroup (5): Diabetic rats treated with basal diet containing $10 \%$ DBMB. 


\section{Egyptian J. of Nutrition Vol. XXXIII No. 2 (2018)}

During the experimental period, feed intake $(\mathrm{FI})$ was recorded daily per each group, and the animals were weighed initially, twice weekly, and at the end of the experiment (4 weeks). Body weight gain\% (BWG \%) and feed efficiency ratio (FER) were calculated at the end of the experimental period.

\section{Blood collection and organs:}

After 4 weeks of treatment, blood samples of the overnight fasted rats were collected from the abdominal aorta under ether anesthesia then centrifuged. Serum was separated andstored at $-20^{\circ} \mathrm{C}$ until biochemical analysis.

The pancreas, liver and kidney tissues from each rat were dissected out, washed with normal saline solution to remove blood and fixed in $10 \%$ neutral formalin for histopathological examination.

\section{Biochemical Analysis of serum:}

Serum samples were used for determination of glucose according to (Kaplan, 1984), total Cholesterol (Allain et al., 1974), triacylglycerols(Fossati and Prencipel, 1982), HDL-C (LopesVirella et al., 1977), LDL-C and VLDL-C were calculated by using the method of Friedewald et al., (1972). AST and ALT were measured according to Reitman and Frankel, (1975).Uric acid and urea nitrogen were determined according to the methods described by Fossati et al., (1980), andPatton and Crouch, (1977)respectively.

\section{Histopathological Examination:}

Tissues from liver, kidney and pancreas of the sacrificed rats were examined as described by Bancroft and Cook, (1998). 


\section{Ibrahim S. Salem, Ahmed A. Ameen and Mona S. Mohammed}

\section{Preparation of Pan Bread:}

The standard formula of Pan Bread (control) was prepared according to the method described by A.A.C.C. (2002). Control pan bread was made from $100 \%$ wheat flour. Different formulas of the fortified pan bread were made from a mixture of wheat and banana male bud powder at differentlevels $(2.5 \%, 5 \%, 7.5 \%$ and $10 \%)$.

\section{Sensory Evaluation of pan bread:}

Sensory Evaluation of the prepared breads was carried out according to Amerine et al., (1965). Fresh samples of control and fortified breads with $(2.5 \%, 5 \%, 7.5 \%$ and $10 \%$ DBMB) were given three codes and organoleptically evaluated by (30) panelists from the Faculty of Home Economics, Helwan University. All samples were evaluated for color (Internal, external), texture (Homogeneity of pores, size of pores), taste, odor, general appearance and overall acceptability on five-point hedonic scale.

\section{Statistical Analysis:}

The statistical analyses were carried out by using SAS (2006). The results were expressed as mean \pm SD. Data were subjected to one-way analysis of variance (ANOVA). The differences between means were tested for significance using least significant difference (LSD) test at $(P<0.05)$ (Steel and Torri, 1980).

\section{Results and Discussion}

\section{Chemical composition of dried banana male bud:}

The type of dried banana male bud was analyzed and illustrated in table (1).The (\%) of carbohydrate was the highest in dried banana male bud (45.96\%), followed by protein, ash and crude fiber $(15.55,15.28$ and $13.14 \%)$, respectively. Moisture and fat 


\section{Egyptian J. of Nutrition Vol. XXXIII No. 2 (2018)}

contents of dried banana male bud were (7.24 and $2.83 \%$ ), respectively. This compositional profile is in agreement with Fingolo et al., (2012) who analyzed the nutritional composition of the inflorescences (male flowers and bracts) of Musa acuminata, cultivar (ouro). The sample composition analysis showed percentual average value for moisture, protein, fat and ash as $8.21,14.50,4.04$ and 14.43 , respectively.

\section{Sugars composition of dried banana male bud ( $\mathrm{g} / \mathbf{1 0 0 g})$ :}

The sucrose, glucose and fructose contents of dried banana male bud are given in table (2). Data showed that, dried banana male bud has a low content of sucrose, glucose and fructose which were $(0.856,0.122$ and $0.121 \%)$, respectively.

Effect of DBMB on feed intake, feed efficiency ratio and body weight gain \%:

The effect of four levels of DBMB on feed intake (FI), feed efficiency ratio (FER) and body weight gain \% (BWG \%) of diabetic ratspresented in table (3). Mean value of feed intake in the positive control group (un-treated diabetic rats) increased than those of negative control group (normal rats) $(7.02$ vs. $5.6 \mathrm{~g} /$ day/rat, respectively).These results agree with Bhaskar et al., (2011b) and Ramu et al., (2016) who showed that, the diet intake (g/day) of diabetic rats increased, as compared to control group (starch-fed control).

Treating diabetic rats with $2.5 \%, 5 \%, 7.5 \%$ and $10 \%$ DBMB showed gradual increase in feed intake, at the same time, treating diabetic groups with $5 \%, 7.5 \%$ and $10 \%$ DBMB increased feed intake, as compared to positive control group and this is showed improvement in feed intake of rats, unlike the group that treated with 


\section{Ibrahim S. Salem, Ahmed A. Ameen and Mona S. Mohammed}

2.5\% DBMB showed lower feed intake value than negative and positive control groups. The obtained results are in the line with (Liyanage et al., 2016) who demonstrated that, there was no difference in feed intake among the experimental rats groups [control $\operatorname{diet}(\mathrm{CN}), 0.5 \%$ cholesterol $\operatorname{diet}(\mathrm{CD})$ and $0.5 \%$ cholesterol diet $+21 \%$ banana blossom (CDB)], at the same time, feed intake (g) in CDB group recorded the highest mean value, as compared to $C N$ and $C D$ groups.

As shown in table (3), data revealed that mean $\pm S D$ of FER of the control $(+)$ was significantly $(P<0.05)$ reduced,compared to control $(-)(0.57 \pm 0.06$ vs. $9.90 \pm 2.82)$. Feeding diabetic rats on basal diet containing $2.5 \%, 5 \%$ and $7.5 \%$ DBMB resulted in nonsignificant changes in FER, as compared to positive diet (control positive), while $10 \%$ DBMB groupcaused significant $(P<0.05)$ increase in FER value, compared to control $(+)$ and induced the best improvement in this parameter.

BWG\% of the positive control group (un-treated diabetic rats) showed significant decrease, as compared to negative control group (healthy rats). Feeding diabetic rats on $2.5 \%$ and $5 \%$ DBMB showed non-significant changes, while the other two higher levels $7.5 \%$ and $10 \%$ of DBMB induced significant increase in BWG\%, as compared to positive control group. In this respect, Ramu et al., (2016) who found that, oral administration of ethanol extract of banana flower (100 \& $200 \mathrm{mg} / \mathrm{kg} \mathrm{b.} \mathrm{wt.),} \mathrm{its} \mathrm{active} \mathrm{compounds} \mathrm{Umbelliferone} \mathrm{and}$ Lupeol at $(100 \mathrm{mg} / \mathrm{kg} \mathrm{b}$. wt.) to the diabetic rats enhanced $(22.68 \%$, $26.52 \%, 17.77 \%$ and $15.11 \%$, respectively) the body weight during the course of the experiment ( 28 days). 


\section{Egyptian J. of Nutrition Vol. XXXIII No. 2 (2018)}

\section{Effect of dried banana male bud on serum Glucose:}

As shown in table (4), the mean value of serum glucose ( $\mathrm{mg} / \mathrm{dl}$ ) of untreated diabetic rats (positive control group) which fed on basal diet was significantly higher $(P<0.05)$ than normal rats (negative control group) which also fed on basal diet (343.33 \pm 60.28 vs. $81.67 \pm 37.53 \mathrm{mg} / \mathrm{dl}$ ), respectively. The results indicated that, all treated diabetic rats with dried banana male bud at $(2.5 \%, 5 \%, 7.5 \%$ and $10 \%)$ led to significant decrease $(P<0.05)$ in mean values of serum glucose gradually, as compared to control (+) group. From the obtained results, it could be observed a negative correlation between glucose levels and the dried banana male bud levels. However, with the increasing amount of DBMB (from $5 \%$ to $10 \%$ ) in the diabetic rats' diets is more effective in reducing serum glucose levels of diabetic rats toward normal value of the normal rats (negative control group).

In this respect, Pari and Umamaheswari, (2000) who indicated that, oral administration of $0.15,0.20$ and $0.25 \mathrm{~g} / \mathrm{kg}$ body weight of the chloroform extract of banana flowers (BFEt) for 30 days resulted in a significant reduction in blood glucose and the effect of BFEt was more prominently seen in the case of animals given 0.25 $\mathrm{g} / \mathrm{kg}$ body weight.Dhanabal et al., (2005), reported that Oral administration of the ethanolic extract of flowers of Musa sapientum (Musaceae) showed significant blood glucose lowering effect at 200 $\mathrm{mg} / \mathrm{kg}$ in alloxan induced diabetic rats. Musa sapientum induced blood sugar reduction may be due to possible inhibition of free radicals and subsequent inhibition of tissue damage induced by alloxan. The antidiabetic activity observed in this plant may be attributed to the presence of flavonoids, alkaloids, steroid and glycoside principles.In another study by Ramu et al., (2016) who reported that, the ethanol extract of banana flower (EF) and its isolated Umbelliferone and Lupeol significantly reduced the plasma 


\section{Ibrahim S. Salem, Ahmed A. Ameen and Mona S. Mohammed}

glucose levels (in groups receiving $200 \mathrm{mg} / \mathrm{kg}$ b.wt. of EF followed by $100 \mathrm{mg} / \mathrm{kg}$ b.wt. of EF, Umbelliferone and Lupeolalong with a corresponding increase in the insulin levels. The observed hypoglycaemic effect may be due to either regeneration of $\beta$-cells or enhanced insulin sensitivity to the target tissues.

The chemical composition analysis of the tested dried banana male bud revealed that it has a high content of fiber with a low content of sugars, and these results are in the line of the work of (Bhaskar et al., 2011b) who stated that banana flower and pseudostem are rich in dietary fiber with low glycemic index which could facilitate slow absorption of glucose along the passage through gastro-intestinal tract and also have a high content of total polyphenols and antioxidants, which could play a crucial role in reducing the oxidative stress-induced glycation and formation of AGEs during diabetes, besides the anti-diabetic property, in the same line the observed reduction in hyperglycemia levels and the modulation in the activities of antioxidant defense enzymes viz., catalase (CAT), superoxide dismutase (SOD) and glutathione peroxidase (GPx) may be due to the combined effect of antioxidants and bioactives present in banana flower and pseudostem along with dietary fiber and its fermented products, including butyric acid (Bhaskar et al., 2011a).

\section{Effect of dried banana male bud on lipid fractions profile:}

As shown in table (5), cholesterol, triacylglycerol and VLDL-C levels were increased significantly $(P<0.05)$ in un-treated diabetic rats fed on basal diet (control positive group) while, HDL-C and LDL-C weren't significantly changed,compared to healthy rats which also fed on basal diet (control negative group).Administration of DBMB gradually retrieved the lipid fractions with various levels to near 


\section{Egyptian J. of Nutrition Vol. XXXIII No. 2 (2018)}

control values. The best treatments that restored the lipid fractions to near the healthy control values were $7.5 \%$ and $10 \%$ DBMB. Studies have shown that amelioration of the insulin secreting cells could have probably led to the improvement in the levels of lipoprotein lipases which was observed after the ethanol extract of banana flower, Umbelliferone and Lupeoltreatment at the dose of (100 and 200 $\mathrm{mg} / \mathrm{kg}$ b. wt.) leading to normal blood lipid profile Ramu et al., (2016). Also Liyanage et al., (2016) found that, banana blossom incorporated experimental diets at $21 \%$ powder, could modulate the hypocholesterolaemic response in high-cholesterol fed rats, and this was supported by higher crude fibre content in banana blossoms.

\section{Effect of dried banana male bud on liver function:}

Table (6)illustrates the effect of four levels of DBMB on liver enzymes (AST\& ALT) of the diabetic rats. Feeding diabetic rats on basal diet (control positive) resulted in significant increase in serum AST and ALT, as compared to healthy rats (control negative) fed on basal diet. While, feeding diabetic rats on basal diet containing $2.5 \%$, $5 \%, 7.5 \%$ and $10 \%$ DBMB revealed significant gradual decrease with increasing the levels of treatment. From the results in this table it could be concluded that, the best levels of DBMB that significantly $(\mathrm{P}<0.05)$ normalized liver function of the diabetic rats at the end of the experiment was $10 \%$. In this respect, Ramu et al., (2016) indicated that, the ethanol extract of banana flower (100 and 200 $\mathrm{mg} / \mathrm{kg} \mathrm{b}$. wt.) revealed wielded positive impacts in alloxan induced diabetic rats by reversal of altered activities of hepatic marker enzymes viz., aspartate transaminase (AST) and alanine transaminase (ALT). Lower serum AST level in 21\% banana blossom fed rats showed that banana blossom had a hepatoprotective ability by reducing oxidative stress induced by high cholesterol diet $(0.5 \%$ cholesterol) in the experimental rats, these data were further 


\section{Ibrahim S. Salem, Ahmed A. Ameen and Mona S. Mohammed}

supported by observed higher antioxidant activity and polyphenol content in banana blossoms (Liyanage et al., 2016).

\section{Effect of dried banana male bud on kidney function:}

As shown in table (6), control positive group (untreated diabetic rats) revealed significant increase $(P<0.05)$ in serum uric acid and urea nitrogen, compared with those of control negative group (healthy rats). Feeding diabetic rats on basal diet containing treatment showed gradual decrease in mean values of serum uric acid and urea nitrogen with increasing the levels of DBMB, and the best resultswere achieved in diabetic groups that treated with the highest level (10\%) of DBMB. The obtained results are in the line with Talubmook and Buddhakala (2013), who confirmed that the extract of $M$. sapientumflowers $(250 \mathrm{mg} / \mathrm{kg})$ decreased blood urea nitrogen and creatinine.

\section{Sensory Evaluation of pan bread:}

Table (7) shows the sensory evaluation of pan bread (control and fortified with banana male bud powder at different levels [2.5\%, $5 \%, 7.5 \%$ and $10 \%]$. The sensory evaluation included the general appearance, color (Internal, external), texture (Homogeneity of pores, size of pores), taste, odor and overall acceptability which translated to a descriptive category as follows: excellent (5), very good (4), good (3), acceptable (2) and poor (1).

Data in this table showed that, the control pan bread recorded the highest scores for all sensory attributes compared with banana male bud powder (BMBP) fortified pan breads. The obtained data revealed that, there are significant difference $(P<0.05)$ in the mean values of sensory evaluation of pan bread containing BMBP at $2.5 \%$, $5 \%, 7.5 \%$ and $10 \%$, compared with control bread across the sensory 


\section{Egyptian J. of Nutrition Vol. XXXIII No. 2 (2018)}

parameters [general appearance, color (Internal, external) and overall acceptability].However, pan bread made with 5\% BMBP received the highest scores than pan bread containing (2.5\%, $7.5 \%$ and $10 \%$ BMBP).

On the other hand, the sensory parameters [texture (Homogeneity of pores), taste and odor] tested by panelists showed that there is no significant difference $(P>0.05)$ exist between the fortified bread with BMBP at $(2.5 \%$ \& $5 \%)$ and control bread, meanwhile, mean values of the other bread with $7.5 \%$ and $10 \%$ BMBP showed that there is significant $(\mathrm{P}<0.05)$ difference when compared with control bread. The values of the sensory parameter texture (size of pores) showed that, bread with 5\% BMBP not significant different $(P>0.05)$ with control bread, while significant $(\mathrm{P}<0.05)$ exist between bread with 2.5\%, 7.5\% and 10\% BMBP and control bread.

From the obtained results, it could be concluded that, fortified pan bread with banana male bud powder at $5 \%$ showed the best results. This result agree with Elaveniya and Jayamuthunagai, (2014) who found that, the best percent of banana blossom powder that showed good appearance was 5\% from the incorporation of banana blossom powder at various concentrations (1\% -6\%) in biscuits, and Suliman, (2012) who determined the physicochemical and sensory attributes of pretzel stick that was partially substituted with four different levels $(0 \%, 5 \%, 10 \%$, and $15 \%)$ of banana (Musa Acuminata $x$ BalbisianaColla Cv. Awak) flower flour (BFF). The results showed that $5 \%$ substitution of BFF in the pretzel sticks was the best percentage for substitution as it could improve pretzel sticks nutritional value as well as maintaining its sensory characteristics. 


\section{Ibrahim S. Salem, Ahmed A. Ameen and Mona S. Mohammed}

\section{Histopathological Results:}

Histopathological results gave steady confirmation to all the biochemical parameters studied. Microscopical examination of the control negative group (healthy rats) revealed that, rats' liver showed normal hepatocytes, blood sinusoids, central vein, and portal tract (photo 1a), kidneys showed normal renal glomeruli and renal tubules (photo 1b), and Pancreas showed normal pancreatic acini, islets, and duct (photo 1c). Regarding histopathological examination of control positive group (un-treated diabetic rats), liver showed diffuse vacuolar degeneration, compressed blood sinusoids, and congested central vein (photo 2a), kidneys revealed vacuolation of some renal tubular epithelium, and necrosis of others (photo $\mathbf{2 b}$ ), and pancreas showed interstitial blood vessels dilatation with thickened wall, together with degeneration of some pancreatic acini (photo 2c).

Considering the initial treated diabetic group (diet contained $2.5 \% \mathrm{DBMB}$ ), there were dilated and congested hepatoportal blood vessel in liver (photo 3a), kidneys showed dilated and congested interstitial blood vessel (photo $\mathbf{3 b}$ ), and pancreas revealed interlobular edema (photo $3 \mathrm{c}$ ). In photo (4a) the histopathological examination of liver in the treated diabetic group with 5\% DBMB showed that, there was focal area of necrosis infiltrated with mononuclear cells, while in photo (4b) kidneys showed slight congestion of the interstitial blood vessel, and photo (4c) illustrated that,there was slight interlobular edema in pancreas.

Liver of the diabetic group treated with 7.5\% DBMB revealed slightly congested central vein, with no changes in the hepatocytes (photo 5a), Kidneys showed normal renal glomeruli and renal tubules in photo (5b), and in photo (5c) Pancreas showed slight interlobular edema. Referring the final treated group (diet contained 10\% DBMB); 


\section{Egyptian J. of Nutrition Vol. XXXIII No. 2 (2018)}

there were marked improvement, normal hepatocytes, blood sinusoids, central vein, and portal tract in liver (photo 6a), normal renal glomeruli and renal tubules of kidney (photo $6 \mathbf{b}$ ), and normal pancreatic acini, islets, and duct (photo 6c).

From the above mentioned data it could be concluded that, there were a noticed improvements in the liver, kidney and Pancreas tissues of the diabetic group that received treatment with $7.5 \%$ DBMB, however, the best results of the histopathological examination that overcome the all previous changes in liver, kidney and pancreas of the diabetic groups andlooked like the negative control group (healthy rats) with no histopathological changes, were achieved in the last diabetic group which treated with $10 \%$ dried banana male bud.In this respect, study by Ramu et al., (2016) who reported that, the histopathological observations revealed a marked regeneration of the pancreatic $\beta$-cells in the treated diabetic rats with the ethanol extract of banana flower and its isolated compounds (Umbelliferone and Lupeol) and were similar to the normal control group of rats.

\section{Conclusion}

It could be concluded that dried banana flower (banana male bud) possesses potent hypoglycemic activity and has therapeutic effects. The most effective ratio of the treatment with DBMB was $10 \%$. Further investigations are required to detect the active compounds that are responsible for its anti-diabetic activity and its biological effect in order to develop a new natural drug for treatment of diabetes. In addition, diabetic patients can be recommended to consume banana flower in their regular diet as a new vegetable for the management of diabetes. 
Ibrahim S. Salem, Ahmed A. Ameen and Mona S. Mohammed

Table (1): Chemical composition of dried banana male bud (g/100g)

\begin{tabular}{c|c}
\hline Nutrients & Amounts \\
\hline Moisture & 7.24 \\
\hline Protein & 15.55 \\
\hline Fat & 2.83 \\
\hline Ash & 15.28 \\
\hline Crude fiber & 13.14 \\
\hline Total carbohydrate & 45.96 \\
\hline
\end{tabular}

Table (2): Sugar composition of dried banana male bud ( $g / 100 \mathrm{~g})$

\begin{tabular}{c|c}
\hline Sugars content & Amounts \\
\hline Sucrose & 0.856 \\
\hline Glucose & 0.122 \\
\hline Fructose & 0.121 \\
\hline
\end{tabular}




\section{Egyptian J. of Nutrition Vol. XXXIII No. 2 (2018)}

Table (3): Effect of dried banana male bud on feed intake (FI), feed efficiency ratio (FER) and body weight gain \% (BWG\%)of diabetic rats (Mean \pm SD)

\begin{tabular}{c|c|c|c}
\hline $\begin{array}{c}\text { Rarameters } \\
\text { Groups }\end{array}$ & $\begin{array}{c}\text { Feed intake } \\
\text { (g/day/rat) }\end{array}$ & FER & BWG (\%) \\
\hline Control (-) & 5.6 & $9.90 \pm 2.82^{\mathrm{A}}$ & $35.73 \pm 11.52^{\mathrm{A}}$ \\
\hline Control (+) & 7.02 & $0.57 \pm 0.06^{\mathrm{C}}$ & $2.47 \pm 1.05^{\mathrm{C}}$ \\
\hline $2.5 \%$ DBMB & 4.9 & $0.78 \pm 0.210^{\mathrm{C}}$ & $3.48 \pm 3.62^{\mathrm{C}}$ \\
\hline $5 \%$ DBMB & 8.3 & $0.87 \pm 0.83^{\mathrm{C}}$ & $4.78 \pm 1.78^{\mathrm{C}}$ \\
\hline $7.5 \%$ DBMB & 9.1 & $1.35 \pm 1.33^{\mathrm{C}}$ & $8.80 \pm 8.36^{\mathrm{B}, \mathrm{C}}$ \\
\hline $10 \%$ DBMB & 13.9 & $4.54 \pm 0.29^{\mathrm{B}}$ & $17.88 \pm 1.95^{\mathrm{B}}$ \\
\hline
\end{tabular}

DBMB: Dried banana male bud. Means in the same column with different superscripts are significantly different $(P<0.05)$.

Table (4): Effect of dried banana male bud on serum Glucose levels of diabetic rats (Mean $\pm S D$ )

\begin{tabular}{c|c}
\hline Groups & Glucose $(\mathrm{mg} / \mathrm{dl})$ \\
\hline Control $(-)$ & $81.67 \pm 37.53^{\mathrm{C}}$ \\
\hline Control $(+)$ & $343.33 \pm 60.28^{\mathrm{A}}$ \\
\hline $2.5 \%$ DBMB & $162.50 \pm 60.76^{\mathrm{B}}$ \\
\hline $5 \%$ DBMB & $131.25 \pm 58.93^{\mathrm{B}, \mathrm{C}}$ \\
\hline $7.5 \%$ DBMB & $120.00 \pm 26.22^{\mathrm{B}, \mathrm{C}}$ \\
\hline $10 \%$ DBMB & $102.50 \pm 2.50^{\mathrm{B}, \mathrm{C}}$
\end{tabular}

DBMB: Dried banana male bud. Means in the same column with different superscripts are significantly different $(P<0.05)$. 


\section{Ibrahim S. Salem, Ahmed A. Ameen and Mona S. Mohammed}

Table (5): Effect of dried banana male bud on serum lipid fractions of diabetic rats (Mean \pm SD)

\begin{tabular}{c|c|c|c|c|c}
\hline \multirow{2}{*}{ Groups } & \multicolumn{5}{|c}{ lipid fractions (mg/dl) } \\
\cline { 2 - 6 } & cholesterol & Triacylglycerol & HDL-C & LDL-C & VLDL-C \\
\hline \multirow{2}{*}{ Control (-) } & $90.00 \pm$ & $35.60 \pm$ & $31.00 \pm$ & $59.20 \pm$ & $7.12 \pm$ \\
& $19.00^{\mathrm{B}}$ & $9.26^{\mathrm{C}}$ & $0^{\mathrm{A}}$ & $12.83^{\mathrm{A}}$ & $1.85^{\mathrm{C}}$ \\
\hline \multirow{2}{*}{ Control (+) } & $118.75 \pm$ & $95.25 \pm$ & $21.00 \pm$ & $77.88 \pm$ & $19.05 \pm$ \\
& $3.59^{\mathrm{A}}$ & $11.84^{\mathrm{A}}$ & $2.65^{\mathrm{A}}$ & $13.35^{\mathrm{A}}$ & $2.37^{\mathrm{A}}$ \\
\hline \multirow{2}{*}{$2.5 \% \mathrm{DBMB}$} & $114.00 \pm$ & $81.50 \pm$ & $21.20 \pm$ & $73.93 \pm$ & $16.30 \pm$ \\
& $5.00^{\mathrm{A}}$ & $6.50^{\mathrm{A}, \mathrm{B}}$ & $5.07^{\mathrm{A}}$ & $12.07^{\mathrm{A}}$ & $1.30^{\mathrm{A}, \mathrm{B}}$ \\
\hline \multirow{2}{*}{$5 \% \mathrm{DBMB}$} & $113.67 \pm$ & $63.67 \pm$ & $27.00 \pm$ & $72.70 \pm$ & $12.73 \pm$ \\
& $26.54^{\mathrm{A}}$ & $30.09^{\mathrm{B}, \mathrm{C}}$ & $7.26^{\mathrm{A}}$ & $7.910^{\mathrm{A}}$ & $6.02^{\mathrm{B}, \mathrm{C}}$ \\
\hline \multirow{2}{*}{$7.5 \% \mathrm{DBMB}$} & $106.20 \pm$ & $51.00 \pm$ & $27.00 \pm$ & $66.80 \pm$ & $10.20 \pm$ \\
& $11.26^{\mathrm{A}, \mathrm{B}}$ & $19.710^{\mathrm{C}}$ & $12.17^{\mathrm{A}}$ & $15.81^{\mathrm{A}}$ & $3.96^{\mathrm{C}}$ \\
\hline \multirow{2}{*}{$10 \%$ DBMB } & $106.00 \pm$ & $49.00 \pm$ & $29.00 \pm$ & $66.70 \pm$ & $9.80 \pm$ \\
& $8.25^{\mathrm{A}, \mathrm{B}}$ & $25.16^{\mathrm{C}}$ & $7.07^{\mathrm{A}}$ & $3.70^{\mathrm{A}}$ & $5.03^{\mathrm{C}}$ \\
\hline
\end{tabular}

DBMB: Dried banana male bud.Means in the same column with different superscripts are significantly different $(P<0.05)$. 
Egyptian J. of Nutrition Vol. XXXIII No. 2 (2018)

Table (6): Effect of dried banana male bud on liver and kidney functions of diabetic rats (Mean \pm SD)

\begin{tabular}{|c|c|c|c|c|}
\hline \multirow{2}{*}{ Groups } & AST & $\mathrm{ALT}$ & Uric acid & Urea nitrogen \\
\hline & \multicolumn{2}{|c|}{$\mathrm{U} / \mathrm{I}$} & \multicolumn{2}{|c|}{$\mathrm{mg} / \mathrm{dl}$} \\
\hline Control (-) & $\begin{array}{c}171.50 \pm \\
13.50^{\mathrm{B}}\end{array}$ & $\begin{array}{c}23.00 \pm \\
13.88^{\mathrm{B}}\end{array}$ & $\begin{array}{c}1.08 \pm \\
0.38^{\mathrm{B}}\end{array}$ & $\begin{array}{c}76.33 \pm \\
4.51^{\mathrm{B}}\end{array}$ \\
\hline Control (+) & $\begin{array}{c}234.60 \pm \\
51.88^{A}\end{array}$ & $\begin{array}{c}44.00 \pm \\
16.29^{A}\end{array}$ & $\begin{array}{c}2.50 \pm \\
0^{A}\end{array}$ & $\begin{array}{c}174.00 \pm \\
34.39^{A}\end{array}$ \\
\hline $2.5 \%$ DBMB & $\begin{array}{c}226.75 \pm \\
43.34^{\mathrm{A}, \mathrm{B}}\end{array}$ & $\begin{array}{l}38.33 \pm \\
11.15^{A, B}\end{array}$ & $\begin{array}{c}1.90 \pm \\
0.92^{A, B}\end{array}$ & $159.25 \pm 88.88^{A, B}$ \\
\hline $5 \%$ DBMB & $\begin{array}{c}223.67 \pm \\
39.63^{A, B}\end{array}$ & $\begin{array}{c}35.50 \pm \\
4.12^{A, B}\end{array}$ & $\begin{array}{l}1.87 \pm \\
0.38^{A, B}\end{array}$ & $134.50 \pm 81.39^{A, B}$ \\
\hline $7.5 \%$ DBMB & $\begin{array}{l}198.50 \pm \\
20.14^{A, B}\end{array}$ & $\begin{array}{l}27.67 \pm \\
11.72^{A, B}\end{array}$ & $\begin{array}{l}1.67 \pm \\
0.85^{A, B}\end{array}$ & $106.50 \pm 34.50^{A, B}$ \\
\hline $10 \%$ DBMB & $\begin{array}{c}172.33 \\
\pm 13.20^{\mathrm{B}}\end{array}$ & $25.00 \pm 6.00^{A, B}$ & $\begin{array}{l}1.18 \pm \\
0.43^{\mathrm{B}}\end{array}$ & $\begin{array}{l}98.00 \pm \\
20.51^{\text {A,B }}\end{array}$ \\
\hline
\end{tabular}

DBMB: Dried banana male bud. AST: Aspartate aminotransferase. ALT:Alanine aminotransferase.Means in the same column with different superscripts are significantly different $(\mathrm{P}<0.05)$. 


\section{Ibrahim S. Salem, Ahmed A. Ameen and Mona S. Mohammed}

Table (7): Sensory evaluation (Mean \pm SD) of pan bread (control and fortified with dried banana male bud at different levels).

\begin{tabular}{|c|c|c|c|c|c|c|c|c|}
\hline \multirow{3}{*}{$\begin{array}{c}\text { Samples } \\
\text { of pan } \\
\text { bread }\end{array}$} & \multicolumn{8}{|c|}{ Sensory Evaluation Parameters } \\
\hline & \multirow{2}{*}{\begin{tabular}{c|} 
General \\
appearance
\end{tabular}} & \multicolumn{2}{|c|}{ Color } & \multicolumn{2}{|c|}{ Texture } & \multirow[b]{2}{*}{ Taste } & \multirow[b]{2}{*}{ Odor } & \multirow{2}{*}{$\begin{array}{c}\text { Overall } \\
\text { acceptabi } \\
\text { lity }\end{array}$} \\
\hline & & Internal & External & $\begin{array}{c}\text { Homogeneity } \\
\text { of pores }\end{array}$ & $\begin{array}{c}\text { Size of } \\
\text { pores }\end{array}$ & & & \\
\hline $\begin{array}{l}\text { Control } \\
\text { bread }\end{array}$ & $\begin{array}{l}4.80 \pm \\
0.48^{\mathrm{A}}\end{array}$ & $\begin{array}{l}4.67 \pm \\
0.55^{\mathrm{A}}\end{array}$ & $\begin{array}{l}4.83 \pm \\
0.46^{\mathrm{A}}\end{array}$ & $\begin{array}{l}4.50 \pm \\
0.63^{\mathrm{A}}\end{array}$ & $\begin{array}{l}4.67 \pm \\
0.61^{\mathrm{A}}\end{array}$ & $\begin{array}{l}4.23 \pm \\
0.86^{\mathrm{A}}\end{array}$ & $\begin{array}{c}4.30 \pm \\
0.95^{\mathrm{A}}\end{array}$ & $\begin{array}{c}4.67 \pm \\
0.55^{\mathrm{A}}\end{array}$ \\
\hline $\begin{array}{c}2.5 \% \\
\text { DBMBPB }\end{array}$ & $\begin{array}{c}3.87 \pm \\
1.07^{\mathrm{B}}\end{array}$ & $\begin{array}{c}3.67 \pm \\
1.42^{\mathrm{B}}\end{array}$ & $\begin{array}{l}4.27 \pm \\
0.91^{\mathrm{B}}\end{array}$ & $\begin{array}{l}4.33 \pm \\
0.71^{\mathrm{A}, \mathrm{B}}\end{array}$ & $\begin{array}{l}4.10 \pm \\
0.88^{B}\end{array}$ & $\begin{array}{c}3.90 \pm \\
1.06^{\mathrm{A}}\end{array}$ & $\begin{array}{c}4.47 \pm \\
0.86^{\mathrm{A}}\end{array}$ & $\begin{array}{l}4.00 \pm \\
0.79^{B}\end{array}$ \\
\hline $\begin{array}{c}5 \% \\
\text { DBMBPB }\end{array}$ & $\begin{array}{c}4.13^{ \pm} \\
1.01^{\mathrm{B}}\end{array}$ & $\begin{array}{c}4.03 \pm \\
1.27^{\mathrm{B}}\end{array}$ & $\begin{array}{l}3.97 \pm \\
1.16^{\mathrm{B}, \mathrm{C}}\end{array}$ & $\begin{array}{l}4.27 \pm \\
0.78^{\mathrm{A}, \mathrm{B}}\end{array}$ & $\begin{array}{l}4.23 \pm \\
0.73^{\mathrm{A}, \mathrm{B}}\end{array}$ & $\begin{array}{c}3.97 \pm \\
1.22^{\mathrm{A}}\end{array}$ & $\begin{array}{c}4.20 \pm \\
0.96^{\mathrm{A}}\end{array}$ & $\begin{array}{l}4.17 \pm \\
0.95^{\mathrm{B}}\end{array}$ \\
\hline $\begin{array}{c}7.5 \% \\
\text { DBMBPB }\end{array}$ & $\begin{array}{l}3.70 \pm \\
1.02^{\mathrm{B}}\end{array}$ & $\begin{array}{r}.73 \pm \\
1.05^{\mathrm{B}}\end{array}$ & $\begin{array}{l}3.73^{ \pm} \\
1.23^{\mathrm{C}}\end{array}$ & $\begin{array}{l}3.93 \pm \\
0.94^{\mathrm{B}, \mathrm{C}}\end{array}$ & $\begin{array}{l}3.97 \pm \\
0.96^{\mathrm{B}, \mathrm{C}}\end{array}$ & $\begin{array}{l}3.23 \pm \\
1.04^{\mathrm{B}}\end{array}$ & \begin{tabular}{|c|}
$3.57 \pm$ \\
$1.10^{\mathrm{B}}$
\end{tabular} & $\begin{array}{l}3.45 \pm \\
1.07^{\mathrm{C}}\end{array}$ \\
\hline $\begin{array}{c}10 \% \\
\text { DBMBPB }\end{array}$ & $\begin{array}{l}3.67 \pm \\
1.37 \mathrm{~B}\end{array}$ & $3.70 \pm 1.21 \mathrm{~B}$ & $\begin{array}{l}3.63 \pm \\
1.19 \mathrm{C}\end{array}$ & $\begin{array}{l}3.67 \pm \\
1.03 \mathrm{C}\end{array}$ & $\begin{array}{l}3.57 \pm \\
1.07 \mathrm{C}\end{array}$ & $\begin{array}{l}2.70 \pm \\
1.29 \mathrm{~B}\end{array}$ & \begin{tabular}{|l|}
$3.33 \pm$ \\
$1.32 \mathrm{~B}$
\end{tabular} & $\begin{array}{l}3.37 \pm \\
1.19 \mathrm{C}\end{array}$ \\
\hline
\end{tabular}

DBMBPB: Dried banana male bud pan bread. Means in the same column with different superscripts are significantly different $(P<0.05)$. 
Egyptian J. of Nutrition Vol. XXXIII No. 2 (2018) 
Ibrahim S. Salem, Ahmed A. Ameen and Mona S. Mohammed 
Egyptian J. of Nutrition Vol. XXXIII No. 2 (2018) 
Ibrahim S. Salem, Ahmed A. Ameen and Mona S. Mohammed

\section{References}

A.A.C.C. (2002):

Approved Method of American Association of Cereal Chemists, published by American Association of Cereal Chemists, Ins. St. Paul, Minnesota, USA.

Allain, C.; Poon, L.; Chan, C. and Richmond, W. (1974):

Enzymatic determination of total serum cholesterol. Clinical chemistry, 20: 470-473.

Amerine, M.A.; Pangborn, R.M. and Roessler, E.B. (1965):

Principles of sensory evaluation of food: Food Science and Technology Monographs, Academic Press, New York

AOAC (2005):

Official Methods of Analysis of AOAC International. (Ed. Horwitz, W.), $17^{\text {th }}$ Ed., Suite 500, 481 North Fredric avenue Gaithersburg, Maryland, USA

Bancroft, J.D. and Cook, H.C. (1998):

Manual of histotechnological techniques. Edited by: Churchi Livingstone., New York:243.

BeMiller, J.N. (2010):

Carbohydrate analysis. In: Food analysis, Nielsen S S., (ed). $4^{\text {th }}$ Ed., New York, USA: Springer, pp.

Bhaskar, J.J.; Kumar, P. and Salimath, P.V. (2011a):

Effect of Banana (Musa sp. var. elakki bale) Flower and Pseudostem on Antioxidant and Lysosomal Enzyme Activities in Streptozotocin induced Diabetic Rats. Journal of Pharmacy Research; 4(4): 1087-1091.

Bhaskar, J.J.; Shobha, M.S.; Sambaiah, K. and Salimath, P.V. (2011b):

Beneficial effects of banana (Musa sp. var. elakki bale) flower and pseudostem on hyperglycemia and advanced glycation end-products (AGEs) in streptozotocin-induced diabetic rats. J PhysiolBiochem; 67:415-425. 


\section{Egyptian J. of Nutrition Vol. XXXIII No. 2 (2018)}

Dhanabal, S. P.; Sureshkumar, M.; Ramanathan, M. and Suresh, B. (2005):

Hypoglycemic effect of ethanolic extract of Musa sapientum on alloxan-induced diabetes mellitus in rats and its relation with antioxidant potential.Journal of herbal pharmacotherapy, 5(2): 7-19.

Elaveniya, E. and Jayamuthunagai, J. (2014):

Functional, Physicochemical and Anti-oxidant properties of Dehydrated Banana Blossom Powder and its Incorporation in Biscuits. International Journal of Chem Tech Research; Vol.6, No.9, pp. 4446-4454.

FAO (2002):

FAO Statistic Series. Yearbook Production, 47: 117. Rome: FAO.

Fingolo, C.E.; Braga, J.M.A.; Vieira, A.C.M.; Moura, M.R.L. and Kaplan, M.A.C. (2012):

The natural impact of banana inflorescences (Musa acuminata) on human nutrition.Anais da Academia Brasileira de Ciências, 84(4): 891-898.

Florent, A.W.; Loh, A.M.B. and Thomas, H.E. (2015):

Nutritive Value of three varieties of banana and plantain blossoms from Cameroon. Greener Journal of Agricultural Sciences; 5 (2): 052-061.

Fossati, P. and Principe, L. (1982):

Enzymatic colorimetric determination of total serum triglyceride.Clin. Chem., 28: 2027.

Fossati, P.; Prencipl, L. and Berti, G. (1980):

Egyption colorimetric method of determination of uric acid in serum.Clin. Chem. 26: 227.

Friedwald, W.T.; Leve, R.I. and Fredreickson, D.S. (1972):

Estimation of the concentration of low-density lipoprotein separated by three different methods.Clin. Chem., 18:499502. 
Ibrahim S. Salem, Ahmed A. Ameen and Mona S. Mohammed

Kaplan, L.A. (1984):

Glucose Kaplan, Clin. Chem. the C.V. Mosby Co. Princeton. P.p. $1032-1036$.

Kumar, R.; Arora, V.; Ram, V.; Bhandari, A. and Vyas, P. (2015):

Hypoglycemic and hypolipidemic effect of Allopolyherbal formulations in streptozotocin induced diabetes mellitus in rats. International Journal of Diabetes Mellitus; 3: 45-50.

Liyanage, R.; Gunasegaram, S.; Rizliya, V.; Jayathilake, C.; Weththasinghe, P.; Jayawardana, B.C. and Vidanarachchi, J.K. (2016):

Banana Blossom (Musa acuminate Colla) Incorporated Experimental Diets Modulate Serum Cholesterol and Serum Glucose Level in Wistar Rats Fed with Cholesterol.Cholesterol, 2016.

Lopes-Virella, M.F.; Stone, S.; Ellis, S. and Coldwell, J.A. (1977): Cholesterol determination in high-density lipoprotein separated by three different methods.Clin.Chem, (5); 23:882.

Mahmoud, M.S.; Ahmed, S.M.; Mohammad, S.G. and AbouElmagd, A.M. (2014):

Evaluation of Egyptian Banana Peel (Musa sp.) as a Green Sorbent for Groundwater Treatment.International Journal of Engineering and Technology, 4(11): 648-659.

Nia, B. H.; Khorram, S.; Rezazadeh, H.; Safaiyan, A. and Tarighat-Esfanjani, A. (2018):

The Effects of Natural Clinoptilolite and Nano-Sized Clinoptilolite Supplementation on Glucose Levels and Oxidative Stress in Rats With Type 1 Diabetes. Canadian journal of diabetes, 42(1): 31-35.

Pandurangan, A.; Ahmad, A.; Koul, S.; Sharma, B. M. and Kumar, M. (2013):

Blood Glucose Lowering Potential of Hamelia Patens Stem in alloxan induced diabetic rat. Global Journal of Pharmaceutical Education and Research| July-December, 2(2). 


\section{Egyptian J. of Nutrition Vol. XXXIII No. 2 (2018)}

Pari, L. and Umamaheswari, J. (2000):

Antihyperglycaemic Activity of Musa sapientumFlowers: Effect on Lipid Peroxidation in Alloxan Diabetic Rats. Phytother. Res.; 14, 136-138.

Patel, D.K.; Kumar, R.; Prasad, S.K.; Sairam, K. and Hemalatha, S. (2011):

Antidiabetic and invitro antioxidant potential of Hybanthusenneaspermus (Linn) F. Muell in streptozotocininduceddiabetic rats. Asian Pac. J. Trop.Biomed., 1(4): 316-322.

Patton, C.J. and Crouch, S.R. (1977):

Enzymatic colorimetric for determination of urea in serum.Anal. Chem., 49: 464-469.

Rajesh, N. (2017):

Medicinal benefits of Musa paradisiaca(Banana).International Journal of Biology Research; Volume 2, Issue 2: Page No. 5154.

Ramu, R.; Shirahatti, P.S.; Swamy, S.N.; Zameer, F.; Dhananjaya, B.L. and Prasad, M.N.N. (2016):

Assessment of In Vivo Antidiabetic Properties of Umbelliferone and Lupeol Constituents of Banana (Musa sp. var. Nanjangud Rasa Bale) Flower in Hyperglycaemic Rodent Model.PloS one, 11(3), e0151135.

Reeves, P. G.; Nielsen, F. H. and Fahmy, G. C. (1993):

AIN-93 purified diets for laboratory rodents: Final report of the American Institute of Nutrition and hoc writing committee on the reformulation of the AIN-76A rodent diet. J.Nutr.; 123(11): 1939-1951.

Reitman, S. and Frankel, S. (1975):

A Colorimetric method for the determination of serum glutamic oxaloacetic and glutamic pyruvic transaminases. Am. J. Clin. Path., 28:56. 
Ibrahim S. Salem, Ahmed A. Ameen and Mona S. Mohammed

Salgar, S.D. and Usman, M.R.M.(2015):

Potential for health benefit: Banana flower. Nat Prod Chem Res; (3)6: pp. 160.

SAS (2006):

Statistical Analysis System, SAS User's Guide: Statistics. SAS Institute Inc. Editors, Cary, NC.

Sheng, Z.-W.; Ma, W.-H.; Jin, Z.-Q.; Bi, Y.; Sun, Z.-G.; Dou, H.-T.; Gao, J.-H.; Li, J.-Y. and Han, L.-N. (2010):

Investigation of dietary fiber, protein, vitamin $\mathrm{E}$ and other nutritional compounds of banana flower of two cultivars grown in China. African Journal of Biotechnology; 9(25): 3888-3895.

Siddiq, M.; Ahmed, J.; Lobo, M.G. and Ozadali, F. (eds.) (2012):

Tropical and Subtropical fruits: postharvest physiology, processing and packaging, First Edition. John Wiley \& Sons, Inc. Retrieved from http://books.google.com

Singh, S. (2017):

BANANA BLOSSOM-AN UNDERSTATED FOOD WITH HIGH FUNCTIONAL BENEFITS.International Journal of Current Research; 9(01): 44516-44519.

Steel, R. G. and Torri, J. H. (1980):

Principal and procedures of statistical, biometrical approach.Pbl. Mc Grew Hill Book Company. $2^{\text {nd }}$ Ed. New York, U.S.A

Suliman, M. D. (2012):

Effect of partial substitution of banana flower flour (Musa Acuminata x BalbisianaColla Cv. Awak) on physicochemical and sensory attributes in pretzel sticks (Doctoral dissertation, UniversitiTeknologiMARA). Retrieved from https://scholar.google.com.eg

Swe, K.N.N. (2012):

Study On Phytochemicals and Nutritional Composition Of Banana Flowers Of Two Cultivars (Pheekyan and Thee hmwe). Universities Research Journal; Vol.5, No.1, pp. 1-7. 
Egyptian J. of Nutrition Vol. XXXIII No. 2 (2018)

Talubmook, C. and Buddhakala, N. (2013):

BIOACTIVITIES of ETRACTS from TinosporacrispaSTEMS, AnnonasquamosaLEAVES, Musa sapientumFLOWERS, and Piper sarmentosumLEAVES in DIABETIC RATS. Int. J. Adv. Res. Technol; 2(6), 144-149.

Wickramarachchi, K.S. and Ranamukhaarachchi, S.L. (2005):

Preservation of fiber-rich banana blossom as a dehydrated vegetable. Sci. Asia, 31: 265-271. 


\section{Ibrahim S. Salem, Ahmed A. Ameen and Mona S. Mohammed}

\section{التأثير العلاجي لزهرة المـوز (برعم نبات الموز) على الفئران المصابة بمرض السكري}

إبراهيم سعيد سالـم, أحمد علـي أميـنرمنى صسلاح محمـ

قسم التغذية وعلوم الأطعمة - كلية الاقتصاد المنزلي - جامعة حلوان

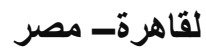

$$
\text { الملخص العربي }
$$

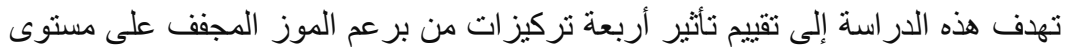

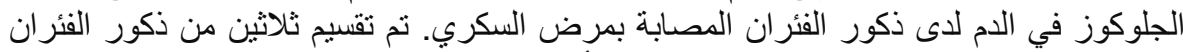

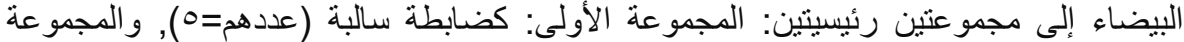

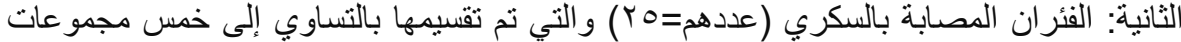

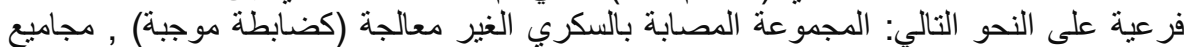

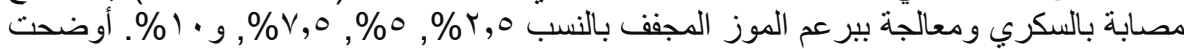

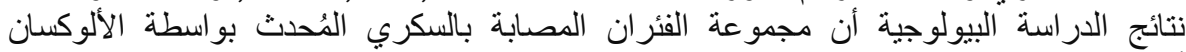

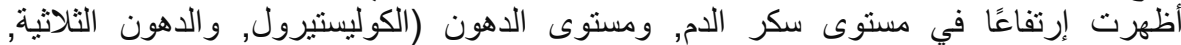

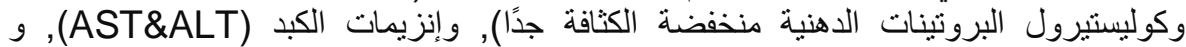

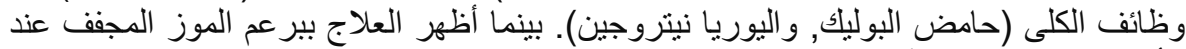

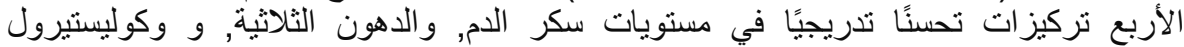

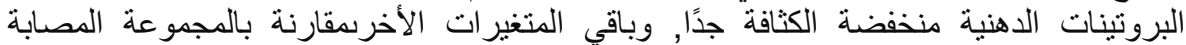

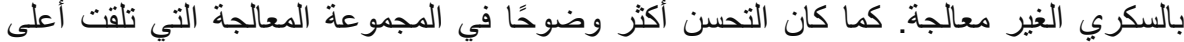

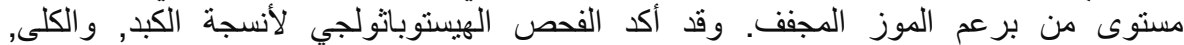

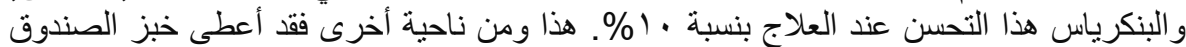

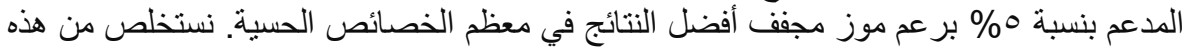
الدراسة أن برعم نبات الموز المجفف له نشاط نشاط خافض لسكر الدم بشكل فعال ويمكن أن بيتخدم كمكل في النظام الغذائي لمرضى الستر السكر. 